Etikonomi

Volume 16 (2), Oktober 2017

P-ISSN: 1412-8969; E-ISSN: 2461-0771

Page $125-144$

\title{
Relationship between Service Quality and Behavioral Intentions: The Mediating Effect of Customer Satisfaction
}

\author{
Azman Ismail ${ }^{1}$, Ilyani Ranlan Rose ${ }^{2}$, Rabaah Tudin ${ }^{3}$, Norazryana Mat Dawi ${ }^{4}$ \\ ${ }^{12}$ Universiti Kebangsaan Malaysia, ${ }^{3}$ UCSI University Kuching Campus, \\ ${ }^{4}$ Sunway University Business School \\ 12azisma12@ukm.edu.my, ${ }^{2}$ nurilyanirose@yahoo.com, ${ }^{3}$ trabaah@googlemail.com, \\ norazryanad@sunway.edu.my
}

\begin{abstract}
This study was undertaken to measure the relationship between service quality, customer satisfaction and behavioral intentions. A survey method was employed to collect data from customers who received treatments at army medical organizations in Malaysia. The outcomes of Smart-PLS path model analysis confirmed that relationship between service qualities features (tangible, reliability, responsiveness, assurance and empatby) with customer satisfaction were positively and significantly correlated with behavioral intentions. This result demonstrates that effect of tangible, reliability, responsiveness, assurance and empathy on behavioral intentions was mediated by customer satisfaction.
\end{abstract}

Keywords: service quality, customer's satisfaction, behavioral intentions

\begin{abstract}
Abstrak
Penelitian ini dilakukan untuk mengukur hubungan di antara kualitas layanan, kepuasan pelanggan dan niat perilaku. Metode survei digunakan untuk mengumpulkan data dari pelanggan yang mendapat perawatan di organisasi medis militer di Malaysia. Hasil analisis model jalur Smart-PLS menegaskan bahwa bubungan antara fitur kualitas layanan (tangible, reliability, responsiveness, assurance dan empathy) dengan kepuasan pelanggan berkorelasi secara positif dan signifikan dengan niat perilaku. Hasil ini menunjuk.kan babwa pengarub fisik, reliabilitas, responsif, jaminan, dan empati terhadap niat perilaku dimediasi oleh kepuasan pelanggan.
\end{abstract}

Kata kunci: kualitas layanan, kepuasan pelanggan, niat prilaku.

Received: May 10, 2017; Revised: June 23, 2017; Approved: July 10, 2017 
Relationship between Service Quality

Azman Ismail, Ilyani Ranlan Rose, Rabaah Tudin, Norazryana Mat Dawi

\section{INTRODUCTION}

Over the past two decades, implementation of service quality has been widely recognized as a critical success factor for retaining existing customers, attracting new customers, increasing satisfaction of shareholders, succeeding business strategies, enhancing critical learning experience, and increasing competitiveness and profitability in a global economy (Buttler, 1995; Ali, et.al., 2016; Brady and Cronin, 2010; Hussain et.al., 2015; Fotaki, 2015). Due to its importance, research on service quality has received a great attention in different types of industries such as banking (Felix, 2017; Sadaf, 2017), supply chain and logistics (Baloch and Jamshed, 2017; Yaprakli and Tuzemen, 2017), higher education (Meštrović, 2017), hospitality (Liat et al., 2017; Widarsyah et al., 2017) and health (Aliman and Mohamad, 2016; Lu and Wu, 2016).

In terms of language perspective, the term service quality is interpreted as subtle, the service activities are difficult to replicate as they are influenced by human attitudes and perceptions (Aryee et.al, 2016; Sriram et.al., 2015; Yuen \& Thai, 2015). In an organization context, it has widely been defined as a long-run overall evaluation (Zeithaml, 1988; Parasuraman et al., 1988), overall appraisal of service at multiple levels in an organization (Brady and Cronin, 2010; Sureshchandar, et.al, 2002); and as a comparison between customer expectations before and after they experience the service (Gronroos, 2007). In this sense, if customers' expectations for service performance match their perceptions then service quality is consider delivered (Gronroos, 1990, 2007; Dabholkar, 2015; Kitapcia, et.al, 2014; Parasuraman, et.al, 1988; Zeithaml, 1988). The discussion shows that satisfaction exists when a customer feels that services delivered by a service provider may fulfill his/her needs, expectations and/or goals.

A review of recent literature relating to workplace quality highlights that service quality has five influential elements: 1) tangible (i.e., physical facilities, equipment, and appearance of workers), 2) reliability (i.e., ability to perform the promised service dependably and accurately), 3) responsiveness (i.e., willingness to help customer and provide prompt service), 4) assurance (i.e., knowledge and courtesy of workers and their abilities to inspire trust and confidence), and 5) empathy (i.e., caring, individualized attention the organization provides its customers) (Parasuraman et.al., 1988; Zeithaml, et.al, 1990). These elements were tested in four service categories: banks, stockbrokers, credit card companies, and companies selling household machinery. The results of this study proved that reliability, responsiveness, assurance, empathy and tangible had met the 
standard of validity and reliability analyses and they were important predictors of customer outcomes, such as customer satisfaction (Berry, et.al, 1985; Parasuraman et.al., 1988; Zeithaml, et.al, 1990). This service quality study has inspired many scholars and practitioners to test and retest the validity and reliability of service quality elements in various types of manufacturing and/or service sector.

To date, many researchers and practitioners still apply, replicate and/or modify the service quality elements in measuring the effect of service quality on customer attitudes and behavior at manufacturing and/or service sectors within and/or outside the Western settings (Izogo and Ogba, 2007; Taap et.al, 2011; Abdullah, et.al, 2011; Etemad-Sajadi and Rizzuto, 2013). Extant studies about successful organization highlight that the ability of service providers to appropriately implement tangible, reliability, responsiveness, assurance and empathy in executing daily job may have a significant impact on positive customers' cognitive and attitude reactions, especially customer satisfaction (Izogo and Ogba, 2015; Yeo, et.al, 2015).

In a customer behaviour perspective, customer satisfaction is often viewed as a function of transaction-specific satisfaction and multiple transaction-specific's satisfaction (Fornell, 1992). This perspective may be viewed as decisions made by customers about the service quality, product quality and price (Parasuraman and Berry, 1991; Zeithaml et.al., 1996), an inner view resulted from customer's own experience from the service, an output of customers' comparison between expected performance and actual performance (Rosen and Suprenant 1998), a series of customer post experience decisions with a product or service over time (Clemes, et.al, 2011; Fournier and Mick, 1999), and a difference between customers' expectations and experience performance after using the particular services (Rahim, et.al, 2010). In quality and marketing management studies, customer satisfaction is normally viewed as an important outcome of service quality (Hussain, et.al., 2015; Silvestri, et.al., 2017).

This phenomenon has been an interesting issue when many workplace quality literature published in the $21^{\text {st }}$ century disclose that relationship between service quality and customers' satisfaction may lead to an enhanced positive customer behaviour, especially behavioral intentions (Chakravarty, 2003; Caruana, 2002). In a customer behavioral perspective, behavioral intentions are broadly viewed based on several approaches such as customers will remain with, or defect from, the company (Zeithaml, et.al, 1996). The construct consists of two major types namely, favorable and unfavorable behavioral 
Relationship between Service Quality

Azman Ismail, Ilyani Ranlan Rose, Rabaah Tudin, Norazryana Mat Dawi

intentions. Favorable behavioral intentions concept is often related to a customer's preference to use services delivered by his/her service provider and this will be manifested in terms of customers readiness to recommend, repurchase intentions, deliver positive word of mouth, customer retention and loyalty (Choi, et.al, 2004; Saibou and Kefan, 2010; Zeithaml, et.al, 1996). In contrast, the concept of unfavorable behavioral intentions is normally associated with negative customer responses, such as switching and complaint behavior (Lobo, et.al, 2007). This indicates that behavior intention is an important outcome of the relationship between service quality and customer satisfaction. In an organizational service quality model, many scholars think that service quality; customers' satisfaction and behavioral intentions are highly interconnected constructs. For example, the competency of service providers to appropriately implement tangible, reliability, responsiveness, assurance and empathy in executing daily job will strongly invoke customers' satisfaction. As a result, it may lead to enhance favorable behavioral intentions (Clemes, et.al, 2011; Gounaris, et.al, 2010; Kitapcia, et.al, 2014).

Even though the nature of this relationship is important, the role of customer satisfaction as a mediating variable has been given little emphasized in the context of army organizations (Azman et.al., 2016; Bahadori et.al., 2014). Many scholars argue that this situation is due to several reasons: first, a number of previous studies have much explained the conceptual definitions and disconfirmation paradigms of effective service quality dimensions in various types of private and public sector (Brady and Cronin, 2010; Gronroos, 2007; Mosahab et al., 2010). Second, many earlier studies have much elaborated internal features of customer satisfaction, such as conceptual definitions, purposes, types and significance of this construct in army organizations. Conversely, the mediating effect of army patients' customer satisfaction has not been attention in the service quality research literature (Azman et.al., 2016; Bahadori, et.al, 2014; Barnes, et.al., 2005; Fethi, et.al., 2012). Third, many previous researches have been conducted by army officers using an applied research methodology to develop service quality systems and link their effect on specific army activities, especially logistics and soldier health in war or peacekeeping operations. This study approach has normally utilized simple descriptive, correlation and/or gap analysis methods to achieve short-term objectives and overcome practical problems (Bahadori, et.al, 2014). Consequently, findings from the above studies have only provided general recommendations and this may not adequate to be used as course of actions by practitioners in understanding the difficulties of service quality concept and executing 
strategic action plans to accomplish service quality goals in army organizations (Azman et.al., 2016; Bahadori et.al, 2014; Barnes et.al., 2005; Fethi et.al., 2012). Hence, this situation triggers the researchers to fill in the gap pf literature by evaluating the mediating effect of customer satisfaction in the relationship between service quality and behavioral intentions.

\section{METHOD}

The study engaged a cross-sectional technique because it allowed the researchers to integrate multiple data collection approach, namely the service quality literature, the semistructured interview, and the actual survey data. This procedure may help the researchers to gather accurate, less bias and high quality data at the studied organizations (Creswell, 1998). The target organization of this study was established in 1960 to serve the wounded and sick military personnel, provide preventive and curative medical care for military personnel and their family. The organization has established a quality management system to upgrade its capacity in providing better medical services during wartime as well as present time, for the quality improvement of military staff and their family's health.

The survey questionnaire consists of three sections: first, service quality features, i.e., tangible (TANGB) had 3 items, reliability (RELBY) had 7 items, responsiveness (RESPS) had 10 items, assurance (ASSRE) had 5 items and empathy (EMPHY) had 4 items that were adapted from Parasuraman et.al. (1985) SERVQUAL scale. TANGB was measured using four dimensions: adequate equipment, suitable equipment, suitable location and communication network. RELBY was measured using four dimensions: solving, good service, schedule and performance. RESPS was measured using four dimensions: feedback, priority, takes care and urgent action. ASSRE was measured using five dimensions: comfortable, polite, confident, no complaint and believe. EMPHY was measured using three dimensions: cooperation, understanding and delivery. Second, customer satisfaction (CUSSN) had 7 items, which were adapted from the quality related customer satisfaction literature (Izogo and Ogba, 2015; Yeo, et.al, 2015). CUSSN was measured using three dimensions: treatment, communication and expectation. Third, behavioral intention (BEHVN) had 5 items that were modified from the quality related behavioral intention literature (Gounaris, et.al, 2010; Kitapcia, et.al, 2014). BEHVN was measured using three dimensions: recommendation, repurchase and word of mouth.

The Smart-PLS is employed to evaluate the survey questionnaire data because it can deliver latent variable scores, avoid small sample size problems, and estimate reflective and 
Relationship between Service Quality

Azman Ismail, Ilyani Ranlan Rose, Rabaah Tudin, Norazryana Mat Dawi

formative models that have many latent and manifest variables (Henseler et.al., 2009). The procedure of analyzing data is: first, validity and reliability of instrument was determined using confirmatory factor analysis. Second, the structural model was assessed using standardized betas $(\beta)$ and $t$ statistics (two tail testing: $t>1.96$ ). Third, value of $R^{2}$ was utilized as a criterion of the overall predictive strength of the model (i.e., 0.19 (weak), 0.33 (moderate) and 0.67 (substantial) (Henseler et.al., 2009). Finally, value of $\mathrm{Q}^{2}$ was used as a measure of the model's predictive relevance (i.e., 0.02 (weak), 0.15 (medium) and 0.35 (large) (Hair et al., 2014).

\section{RESULT AND DISCUSSION}

The data shows that majority of the respondents were males (64.1\%) aged from 21 to 30 years old $(45.3 \%)$ and non-married customers $(83.6 \%)$, army patients $(97.6 \%)$, customers who received ordinary treatments $(93.8 \%)$, and customers who received one time treatment in a month $(75.8 \%)$. Table 1 shows the factor loadings and cross loadings for different constructs. The factor loadings for the variables were greater than 0.70 in their own constructs in the model, showing that all constructs met the criteria of convergent validity analysis (Henseler et al., 2009).

Table 1. Factor loadings and cross-factor loadings for different constructs

\begin{tabular}{|c|c|c|c|c|c|c|c|}
\hline \multirow{2}{*}{ Construct } & \multicolumn{7}{|c|}{ Cross-Factor Loadings } \\
\hline & 1 & 2 & 3 & 4 & 5 & 6 & 7 \\
\hline \multicolumn{8}{|l|}{ 1. TANGB } \\
\hline TANGB1 & 0.817 & & & & & & \\
\hline TANGB2 & 0.831 & & & & & & \\
\hline TANGB3 & 0.861 & & & & & & \\
\hline \multicolumn{8}{|l|}{ 2. RELBY } \\
\hline RELBY1 & & 0.830 & & & & & \\
\hline RELBY2 & & 0.896 & & & & & \\
\hline RELBY3 & & 0.802 & & & & & \\
\hline RELBY4 & & 0.784 & & & & & \\
\hline RELBY5 & & 0.795 & & & & & \\
\hline RELBY6 & & 0.797 & & & & & \\
\hline RELBY7 & & 0.841 & & & & & \\
\hline RELBY8 & & 0.849 & & & & & \\
\hline \multicolumn{8}{|l|}{ 3. RESPS } \\
\hline RESPS1 & & & 0.848 & & & & \\
\hline RESPS2 & & & 0.819 & & & & \\
\hline RESPS3 & & & 0.877 & & & & \\
\hline RESPS4 & & & 0.874 & & & & \\
\hline RESPS5 & & & 0.908 & & & & \\
\hline
\end{tabular}


Etikonomi Vol. 16 No. 2 Oktober 2017

\begin{tabular}{|c|c|c|c|c|c|c|c|}
\hline \multirow{2}{*}{ Construct } & \multicolumn{7}{|c|}{ Cross-Factor Loadings } \\
\hline & 1 & 2 & 3 & 4 & 5 & 6 & 7 \\
\hline RESPS6 & & & 0.900 & & & & \\
\hline RESPS7 & & & 0.825 & & & & \\
\hline RESPS8 & & & 0.847 & & & & \\
\hline RESPS9 & & & 0.885 & & & & \\
\hline RESPS10 & & & 0.840 & & & & \\
\hline 4. ASSRE & & & & & & & \\
\hline ASSRE1 & & & & 0.814 & & & \\
\hline ASSRE2 & & & & 0.831 & & & \\
\hline ASSRE3 & & & & 0.927 & & & \\
\hline ASSRE4 & & & & 0.889 & & & \\
\hline ASSRE5 & & & & 0.826 & & & \\
\hline 5. EMPHY & & & & & & & \\
\hline EMPHY1 & & & & & 0.773 & & \\
\hline EMPHY2 & & & & & 0.847 & & \\
\hline EMPHY3 & & & & & 0.866 & & \\
\hline EMPHY4 & & & & & 0.873 & & \\
\hline 6. CUSSN & & & & & & & \\
\hline CUSSN1 & & & & & & 0.900 & \\
\hline CUSSN2 & & & & & & 0.867 & \\
\hline CUSSN3 & & & & & & 0.861 & \\
\hline CUSSN4 & & & & & & 0.921 & \\
\hline CUSSN5 & & & & & & 0.869 & \\
\hline CUSSN6 & & & & & & 0.909 & \\
\hline CUSSN7 & & & & & & 0.825 & \\
\hline 7. BEHVN & & & & & & & \\
\hline BEHVN1 & & & & & & & 0.862 \\
\hline BEHVN2 & & & & & & & 0.886 \\
\hline BEHVN3 & & & & & & & 0.896 \\
\hline BEHVN4 & & & & & & & 0.845 \\
\hline BEHVN5 & & & & & & & 0.788 \\
\hline
\end{tabular}

Table 2 shows the results of convergent and discriminant validity analyses. All constructs had the values of average variance extracted (AVE) bigger than 0.5, signifying that they meet the acceptable standard of convergent validity (Barclay, et.al, 1995; Fornell and Larcker, 1981; Henseler et.al., 2009). Meanwhile, all constructs had the values of AVE square root in diagonal larger than the squared correlation with other constructs in off diagonal, confirming that they satisfied the criteria of discriminant validity (Henseler et.al., 2009). 
Table 2. Fornell-Larcker criterion test

\begin{tabular}{lcccccccc}
\hline \multicolumn{1}{c}{ Construct } & AVE & $\mathbf{1}$ & $\mathbf{2}$ & $\mathbf{3}$ & $\mathbf{4}$ & $\mathbf{5}$ & $\mathbf{6}$ & $\mathbf{7}$ \\
\hline 1. TANGB & 0.700 & $\mathbf{0 . 8 3 7}$ & & & & & & \\
2. RELBY & 0.680 & 0.613 & $\mathbf{0 . 8 2 5}$ & & & & & \\
3. RESPS & 0.744 & 0.604 & 0.702 & $\mathbf{0 . 8 6 3}$ & & & & \\
4. ASSRE & 0.737 & 0.404 & 0.562 & 0.559 & $\mathbf{0 . 8 5 9}$ & & & \\
5. EMPHY & 0.707 & 0.530 & 0.526 & 0.631 & 0.384 & $\mathbf{0 . 8 4 1}$ & & \\
6. CUSSN & 0.773 & 0.310 & 0.666 & 0.404 & 0.574 & 0.376 & $\mathbf{0 . 8 7 9}$ & \\
7. BEHVN & 0.733 & 0.236 & 0.507 & 0.376 & 0.524 & 0.441 & 0.745 & $\mathbf{0 . 8 5 6}$ \\
\hline
\end{tabular}

Table 3 shows the results of variance inflation factor and descriptive statistics. The means for the variables assortment range between 5.27 and 5.69, showing that the levels of TANGB, RELBY, RESPS, ASSRE, EMPHY, CUSSN and BEHVN are in the range of high (4) and highest (5) levels. The values of variance inflation factor for the relationships: (a) between the independent variable (i.e., TANGB, RELBY, RESPS, ASSRE, and EMPHY) and the mediating variable (i.e., CUSSN), and between the mediating variable (i.e., CUSSN) and dependent variable (i.e., BEHVN) were lower than 5.0, signifying that the data were not affected by serious multicollinearity problem (Hair et al., 2014). This measurement model has fulfilled the validity criteria. Furthermore, the composite reliability showed values bigger than 0.8 , signifying that all the measurement scale used in this study had high internal consistency. In overall, this result confirms that the instrument has satisfied the criteria of validity and reliability analyses.

Table 3. Collinearity diagnostics, reliability analyses, and descriptive statistics

\begin{tabular}{|c|c|c|c|c|c|}
\hline \multirow[b]{2}{*}{ Construct } & \multirow[b]{2}{*}{ Mean } & \multirow[b]{2}{*}{ Standard Deviation } & \multicolumn{2}{|c|}{$\begin{array}{c}\text { Variance Inflation } \\
\text { Factor }\end{array}$} & \multirow{2}{*}{$\begin{array}{l}\text { Compositc } \\
\text { Reliability }\end{array}$} \\
\hline & & & 6 & 7 & \\
\hline 1. TANGB & 5.61 & .63 & 1.848 & & 0.875 \\
\hline 2. RELBY & 5.54 & .72 & 2.403 & & 0.944 \\
\hline 3. RESPS & 5.69 & .67 & 2.695 & & 0.967 \\
\hline 4. ASSRE & 5.31 & .80 & 1.585 & & 0.933 \\
\hline 5. EMPHY & 5.56 & .63 & 1.774 & & 0.906 \\
\hline 6. CUSSN & 5.27 & .85 & & 1.000 & 0.960 \\
\hline 7. BEHVN & 5.35 & .71 & & & 0.932 \\
\hline
\end{tabular}

Figure 1 shows the relationship between service quality and customer satisfaction. The inclusion of TANGB, RELBY, RESPS, ASSRE, and EMPHY in the analysis had contributed 55 percent in the variance of CUSSN. This result indicates that it provides a moderate support for the overall model. Further, the $\mathrm{Q}^{2}$ value for CUSSN was 0.417 and 
this value was greater than zero. This result has predictive relevance. Further, the outcomes of testing the research hypotheses showed five important findings: first, TANGB not correlated with CUSSN (B=0.156; $t=1.913)$, therefore H1 not supported. Second, RELBY correlated with CUSSN $(\mathrm{B}=0.695 ; \mathrm{t}=5.863)$, therefore $\mathrm{H} 2$ supported. Third, RESPS significantly correlated with CUSSN $(B=0.254 ; \mathrm{t}=2.356)$, therefore $\mathrm{H} 3$ supported. Fourth, ASSRE correlated with CUSSN $(B=0.346 ; \mathrm{t}=4.176)$, therefore H4 supported. Fifth, EMPHY not correlated with CUSSN $(B=0.125 ; \mathrm{t}=1.374)$, therefore $\mathrm{H} 5$ not supported. This result demonstrates that TANGB and EMPHY are not important predictors of CUSSN. Conversely, RELB, RESPS, RESPS and ASSRE are important predictors of CUSSN.

\section{Figure 1. The result of testing hypothesis}

Independent Variable

Dependent Variable

(Service Quality)

$$
\mathrm{R}^{2}=0.551
$$

\begin{tabular}{|l|l}
\hline TANGB \\
\hline RELBY
\end{tabular}

Note: Significant at t $>1.96$

Figure 2 shows the relationship between service quality, CUSSN and BEHVN. The inclusion of TANGB, RELBY, RESPS, ASSRE, and EMPHY in the analysis had contributed 56 percent of the variance in BEHVN. This result indicates that it provides a moderate support for the overall model. Further, the $\mathrm{Q}^{2}$ value for BEHVN was 0.398 and this value was greater than zero. This result shows that the model has predictive relevance.

Further, the outcomes of testing the research hypotheses displayed that relationship between service quality features (i.e., TANGB, RELBY, RESPS, ASSRE, and EMPHY) and CUSSN was significantly correlated with BEHVN $(B=0.745 ; t=16.916)$, therefore H6 
Relationship between Service Quality

Azman Ismail, Ilyani Ranlan Rose, Rabaah Tudin, Norazryana Mat Dawi

was supported. In overall, this result demonstrates that CUSSN does act as an important mediating variable in the relationship between service quality and BEHVN.

Figure 2. The result of testing hypothesis

Independent Variable

Mediating Variable

Dependent Variable

(Service Quality)

$$
R^{2}=0.549
$$

$R^{2}=0.555$

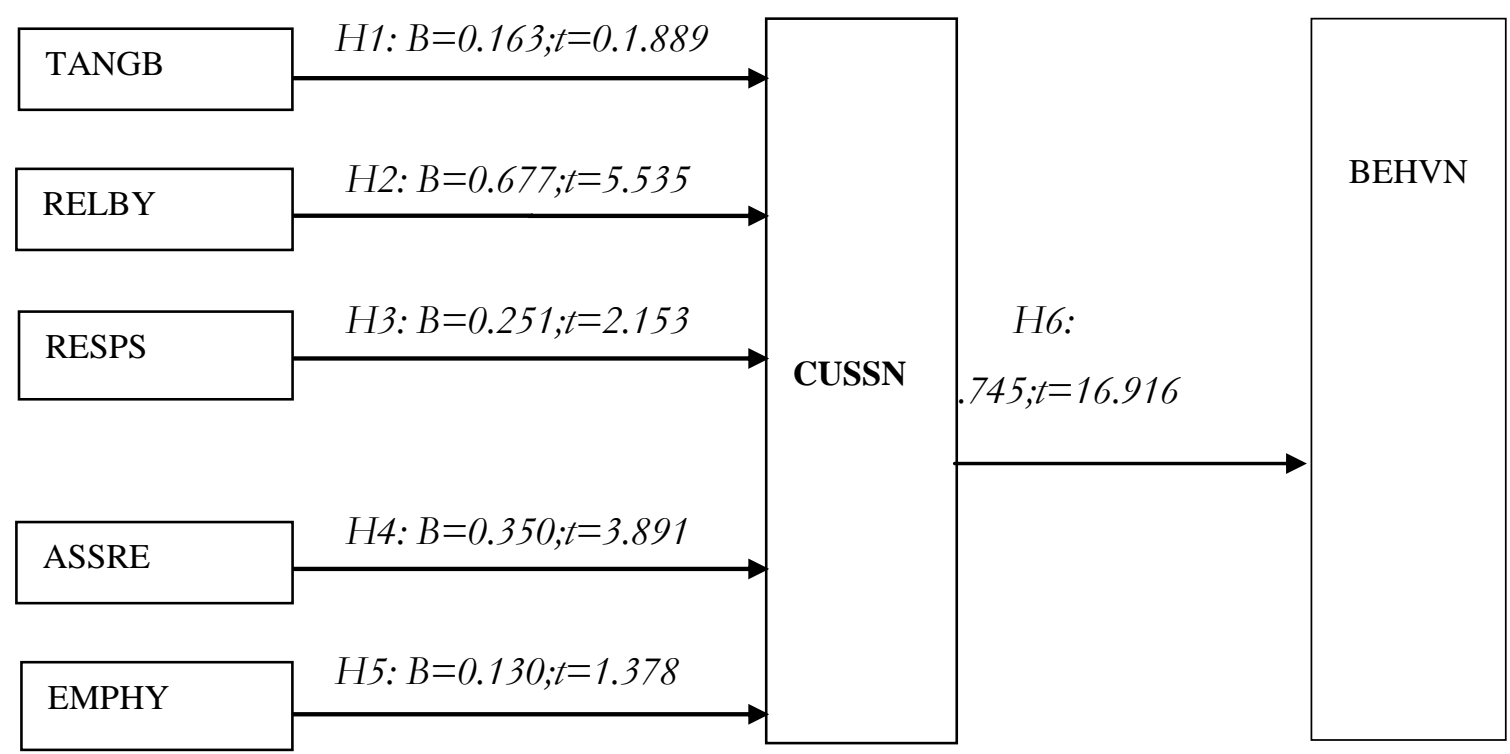

Note: Significant at ${ }^{*} t>1.96$

Table 4 shows the type of mediating effect of CUSSN in the hypothesized model. The results of Variance Accounted For displayed two essential findings. First, CUSSN had fully mediated the effect of TANGB and RELBY on BEHVN. Second, CUSSN had partially mediated the effect of RESPS, ASSRE and EMPHY on BEHVN.

\section{Table 4. The Results of Variance Accounted For}

\begin{tabular}{lll}
\hline \multicolumn{1}{c}{ Relationship between Constructs } & VAF & \multicolumn{1}{c}{ Remark } \\
\hline Relationship between TANGB, CUSSN and BEHVN & 0.959 & Full Mediation \\
Relationship between RELBY, CUSSN and BEHVN & 0.937 & Full Mediation \\
Relationship between RESPS, CUSSN and BEHVN & 0.756 & Partial Mediation \\
Relationship between ASSRE, CUSSN and BEHVN & 0.714 & Partial Mediation \\
Relationship between EMPHY, CUSSN and BEHVN & 0.567 & Partial Mediation \\
\hline
\end{tabular}

The findings of this study show that CUSSN does act as an important mediating variable in the relationship between service quality and BEHVN. In the context of this study, management teams have taken proactive actions to plan, maintain, and monitor their services to customers based on the broad policies and procedures rose by their stakeholders. The study outcomes show that majority of the respondents' view that the 
levels of service quality (i.e., TANGB, RELBY, RESPS. ASSRE and EMPHY), CUSSN and BEHVN are high. This situation explains that the competency of service provider to appropriately implement TANGB, RELBY, RESPS, ASSRE, and EMPHY in performing daily job may lead to greater favorable BEHVN.

This study also provides three major implications: theoretical contribution, robustness of research methodology, and practical contribution. With respect to theoretical contribution, this study reveals that effect of service quality on BEHVN is mediated by CUSSN. This finding also has supported and extended findings of previous researchers like Olorunniwo, et.al (2006), Gounaris, et.al (2010), Udo, et.al (2010), Clemes, et.al (2011), Kitapcia, et.al (2014). The credibility of research methodology is maintained by ensuring that the survey questionnaire met the acceptable standards of validity and reliability analyses. This condition may lead to produce accurate and reliable findings.

The role of service quality as an important variable is consistent with the notion of Parasuraman, et.al. $(1985,1988)$ SERVQUAL model, which posits that tangible, reliability, responsiveness, assurance and empathy are fundamental service quality elements that may strongly invoke customer satisfaction. The notion of this theory has received strong support from the service quality research literature. For example, several previous studies were conducted using a direct effects model to examine service quality in different service organizational settings, like perceptions of customers at education service industry in Korea (Kang, et.al, 2007), 102 customers of a Malaysian public institution of higher learning (Madi and Francis, 2009), 384 customers of automobile repair services in Nigeria (Izogo and Ogba, 2015), 183 customers of manufacturers and freight forwarders in Singapore (Yuen and Thai, 2015), and 313 members of the Korean Port Logistics Association (Yeo, et.al, 2015). The outcomes of these surveys showed that the competency of service providers to appropriately implement tangible, responsive, reliable, assured and emphatic in executing daily job had been important predictors of customers' satisfaction (Azman et.al., 2009; Izogo and Ogba, 2015; Kang, et.al, 2007; Kuo et al., 2009; Yeo, Thai and Roh, 2015).

Customer satisfaction exists when services or products provided by service providers meet their expectations (Oliver, 1997; White and Yu, 2005). Application of this theory in service quality shows that customer satisfactions act as an important link between service quality and customer attitudes and behavior (e.g., behavioral intentions) (Clemes, et.al, 2011; Kitapcia, et.al, 2014). The notion of this theory has received strong support from the service quality research literature. 
Relationship between Service Quality

Azman Ismail, Ilyani Ranlan Rose, Rabaah Tudin, Norazryana Mat Dawi

Several further studies were conducted using an indirect effects model to examine customer satisfaction in different organizational settings, such as perceptions of 317 customers at a US retail bank (Olorunniwo and Hsu, 2006), 150 undergraduate marketing students, 215 non-student customers and $50 \mathrm{MBA}$ students in US service factory (Olorunniwo, et.al, 2006), 240 online shoppers in the database of a leading Internet provider in Greece (Gounaris, et.al, 2010), 349 guests at 15 boutique motels in New Zealand (Clemes, et.al, 2011), 211 senior business administration students at a large public university in the southwest US (Udo, et.al, 2010) and 369 patients facing a range of services in Turkish healthcare system (Kitapcia, et.al, 2014). The outcomes of these surveys showed that the competency of service providers to appropriately deliver tangible, responsive, reliable, assured and empathic in performing daily job had strongly invoked customer satisfaction, which in turn led to an enhanced favorable behavioral intentions (Clemes, et.al, 2011; Gounaris, et.al, 2010; Olorunniwo and Hsu, 2006; Olorunniwo, et.al, 2006; Kitapcia, et.al, 2014; Udo, et.al, 2010). Moreover, in a healthcare setting, Mohamed and Azizan (2015) found out that the mediation effect of patient satisfaction on the relationship between service quality and behavioral intention explains higher variance percentage than the direct effect.

As for practical contribution, the findings of this study can be used as useful recommendations by management to improve the implementation of service quality in organizations. In order to achieve this aim, management should give more attention on the following aspects: first, organizations should provide quality service training program to all staff in order to increase their soft skills and confidence levels in handling different customer attitudes and behavior. Second, better recognitions should be provided to staff who perform high quality service in order to maintain and enhance their engagement and performance in organizations. Third, recruitment policy and career path strategy should be properly set up in order to select knowledgeable and experienced staff to acquire senior management positions. Their capabilities may be used to mentor and coach junior managers and supervisors in practicing service quality based on international standards in quality management. Fourth, knowledge management strategy should be stimulated in order to enhance individuals' expert and knowledge, as well as motivate them to use innovation techniques in delivering service quality to customers. Finally, communication openness should be promoted in order to disseminate service quality policies and procedures via printed materials, online and face-to-face interaction with customers. This 
communication style may decrease misconceptions and increase good rapports between customers and service providers. If these suggestions are heavily considered this may inspire employees to support the organizational service quality goals.

\section{CONCLUSION}

This study tested a conceptual scheme developed based on pertinent service quality research literature. The measurement scale used in this study met the acceptable standards of the validity and reliability analyses. The outcomes of SmartPLS path model analysis confirmed that effect of service quality on behavioral intentions was mediated by customer satisfaction. This result also has supported and enriched service quality studies mostly published in Western countries. Therefore, current research and practice within organizational quality models needs to incorporate TANGB, RELBY, RESPS, ASSRE and EMPHY as key dimensions of the service quality domain. The finding of this study further suggests that the competency of service provider to plan and implement such service quality dimensions in executing daily job will strongly induce subsequent positive customer outcomes (e.g., perceived value, loyalty and fairness). These positive outcomes may lead to maintained and enhanced the organizational performance in an era of global economy.

The conclusion of this study should be cautious with the methodological and conceptual limitations. First, a cross-sectional research design used in this study may not capture detail causal connections between the variables of interest. Second, the outcomes of SmartPLS path model analysis have only measured the relationship between specific indicators for the independent variable and dependent variable. Finally, the sample for this study was only taken from army patients at one army health organizational sector. Due to these limitations, it may decrease the generalizability of this study to other organizational settings.

In future research, several suggestions are forwarded: first, several important respondent characteristics such as gender, age, type of patients and marital status should be used because they may represent similarities and differences of customer perceptions about the implementation of service quality in organizations. Second, other research designs such as longitudinal studies should be utilized to collect data in different times and outcomes of this research design may clearly describe the patterns of change and the direction and magnitude of causal relationships amongst variables of interest. Third, to fully understand the effect of service quality on customer outcomes, this relationship should be assessed in 
Relationship between Service Quality

Azman Ismail, Ilyani Ranlan Rose, Rabaah Tudin, Norazryana Mat Dawi

more than one organization to determine its effectiveness in different organizational settings. Four, other specific theoretical constructs of service quality such as technical quality and interaction quality should be considered because they have widely been acknowledged as an important link between service quality and many aspects of customer outcomes. Five, a larger sample size should be used to characterize the studied population and this may reduce response bias. Finally, other specific elements of behavior intention such as readiness to recommend, intention to repurchase and positive word of mouth should be given attention because their roles are extensively recognized in service quality research literature (Azman et al., 2016; Kitapci et al., 2014; Saibou \& Kefan, 2010). If the issues raised are given more attention this may lead to maintaining and enhancing organizational competitiveness in an era of globalization and knowledge based economy.

\section{REFERENCES}

Abdullah, F., R. Suhaimi., G. Saban. \& J. Hamali. (2011). Bank Service Quality (BSQ) Index: an Indicator of Service Performance. International Journal of Quality and Reliability Management. 28 (5): 542-555.

Ali, F., Y. Zhou., K. Hussain., P.K. Nair., \& N.A. Ragavan. (2016). Does Higher Education Service Quality Effect Student Satisfaction, Image and Loyalty? A Study of International Students in Malaysian Public Universities. Quality Assurance in Education. 24(1): 70 - 94.

Aliman, N.K. \& W.N. Mohamad. (2016). Linking Service Quality, Patients' Satisfaction and Behavioral Intentions: An Investigation on Private Healthcare in Malaysia. Procedia Social and Behavioral Sciences. 224: 141-148.

Aryee, S., Walumbwa, F. O., Seidu, E. Y., \& Otaye, L. E. (2016). Developing and Leveraging Human Capital Resource to Promote Service Quality Testing a Theory of Performance. Journal of management. 42(2): 480-499.

Azman, I., Abdullah, M.M., \& Francis, S.K. (2009). Exploring the Relationships Among Service Quality Features, Perceived Value and Customer Satisfaction. Journal of Industrial Engineering and Management, 2(1): 230-250.

Azman, I., Mohd Helmi, A., Nur Ilyani, R.R., Anis Anisah, A., \& Herwina, R. (2016). Exploring Service Quality Impacts on Customer Satisfaction in Military Medical Centres: Moderating Role of Perceived Value. Jurnal Dinamika Manajemen. 7 (2): 149-165. 
Bahadori, M., Ravangard, R., Yaghoubi, M, \& Alimohammadzadeh, K. (2014). Assessing the Service Quality of Iran Military Hospitals: Joint Commission International Standards and Analytic Hierarchy Process (AHP) Technique. Journal of Education Health Promotion. 3: 98-110.

Baloch, Q.B., \& Jamshed, J. (2017). Service Quality Attributes and Customer Loyalty: Case Study of Pakistan International Air Line. FWU Journal of Social Sciences. 11(1): 92105.

Barclay, D.W., Higgins, C.A., \& Thompson, R.L. (1995). The partial Least Squares (PLS) Approach to Causal Modeling: Personal Computer Adaptation and use an Illustration. Technology Studies. 1(2): 285-324.

Barnes, B.R., Sheys, T., \& Morris, D.S. (2005). Analysing service quality: The case of a US military club. Total Quality Management \& Business Excellence. 16 (8-9): 955-967.

Berry, L.L., Parasuraman, A., \& Zeithaml, V.A. (1985). Quality Counts in Services, Too. Business Horizons. 28 (3): 44-52.

Brady, M.K., \& Cronin, J.J. (2010). Some New Thoughts on Conceptualizing Perceived Service Quality: A Hierarchical Approach. Journal of Marketing. 65(3): 34-49.

Buttler, F. (1995). SERVQUAL: review, critique, research agenda. European Journal of Marketing, Vol. 30 (1): 8-32.

Buttler, F. (1996). Relationship marketing. In Buttle, F (Ed.), Relationship Marketing Theoty and Practice. London, UK: Paul Chapman Publishing Ltd. London, 1-16.

Caruana, A. (2002). Service Loyalty: The Effects of Service Quality and the Mediating role of Customer Satisfaction. European Journal of Marketing, 36(7), 811-828.

Chakravarty, S., Feinberg, R., Rhee, E.Y (2003). Relationships and individual's bank Switching Behavior. Journal of Economic Psychology. 25 (4): 507-527.

Choi, K.S., Cho, W.H., Lee, S., Lee H., \& Kim, C. (2004). The Relationships Among Quality, Value, Satisfaction and Behavioural Intention in Health Care Provider Choice: A South Korean study. Journal of Business Research. 57 (8): 913-921.

Clemes, M.D., Gan, C., \& Ren. M. (2011). Synthesizing the Effects Of Service Quality, Value, And Customer Satisfaction On Behavioral Intentions In The Motel Industry: An Empirical Analysis. Journal of Hospitality \& Tourism Research. 35 (4): 530-568.

Creswell, J.W. (1998). Quality Inquiry and Research Design: Choosing Among Five Traditions, London: SAGE Publication. 
Relationship between Service Quality

Azman Ismail, Ilyani Ranlan Rose, Rabaah Tudin, Norazryana Mat Dawi

Cronin, J.J., Brady, M.K., \& Hult, G.T.M. (2000). Assessing the Effects of Quality, Value, and Customer Satisfaction on Consumer Behavioral Intentions in Service Environments. Journal of Retailing. 76(2): 193-218.

Dabholkar, P. A. (2015). How to Improve Perceived Service Quality by Increasing Customer Participation. In Proceedings of the 1990 Academy of Marketing Science (AMS) Annual Conference. Springer International Publishing: 483-487.

Dabholkar, P.A., Shepherd, D., \& Thorpe, D.I. (2000). A Comprehensive Framework for Service Quality: An Investigation of Critical Conceptual and Measurement Issues Through a Longitudinal Study. Journal of Retailing. 76 (2): 139-173.

Izogo, E.E., \& Ogba, I.E. (2015). Service Quality, Customer Satisfaction and Loyalty in Automobile Repair Services Sector. International Journal of Quality \& Reliability Management. 32 (3): 250-269.

Etemad-Sajadi, R. \& Rizzuto, D. (2013). The Antecedents of Consumer Satisfaction and Loyalty in Fast Food Industry: a Cross-national Comparison between Chinese and Swiss Consumers. International Journal of Quality and Reliability Management. 30 (7): 780798.

Felix, R. (2017). Service Quality and Customer Satisfaction in Selected Banks in Rwanda. Journal of Business, Finance Affairs. 6 (1): 1-11.

Fethi, C., Cigdem, A.G., Ayse Elvan, B., \& Burcu, K. (2012). Effects of Service Quality Dimensions on Customer Satisfaction and Return Intention in Different Hospital Types. Proceedings of the 2012 International Conference on Industrial Engineering and Operations Management Istanbul, Turkey, July 3 - 6, 2012: 518-530.

Fornell, C., \& Larcker, D.F. (1981). Evaluating Structural Equation Models with Unobservable Variables and Measurement Error. Journal of Marketing Research. XVIII: 39-50.

Fornell, C. (1992). A National Customer Satisfaction Barometer: The Swedish Experience. Journal of Marketing, 56: 6-21.

Fotaki, M. (2015). Why and How is Compassion Necessary to Provide Good Quality Healthcare? International journal of health policy and management, 4(4): 199-210.

Fournier, S., \& Micj, D.G. (1999). Rediscovering Satisfaction. The Journal of Marketing. 63 (4): 5-23. 
Gefen, D., \& Straub, D. (2005). A Practical Guide to Factorial Validity Using PLS-Graph: Tutorial and Annotated Example. Communication of the Association for Information Systems. 16: 91-109.

Kondasani, R. \& Panda, R. (2015). Customer Perceived Service Quality, Satisfaction and Loyalty in Indian Private Healthcare. International Journal of Health. 28 (5): 452-467.

Goolsby, J. R., \& Singh, J. (2015). Service Quality: an Agenda for Future Research. In Proceedings of the 1989 Academy of Marketing Science (AMS) Annual Conference. Springer International Publishing, 497-501.

Gounaris, S, Dimitriadis, S., \& Stathakopoulos, V. (2010). An Examination of The Effects of Service Quality and Satisfaction on Customers' Behavioral Intentions in EShopping. Journal of Services Marketing. 24 (2): 142-156.

Gracia, E., Cifre, E., \& Grau, R. (2010). Service Quality: The Key Role of Service Climate and Service Behavior of Boundary Employee Units. Group and Organizational Management. 35(3): 276-298.

Gronroos, C. (1990). Service Management and Marketing: Managing the Moments in Truth in Service Competition. Lexington, MA: Lexington Books.

Gronroos, C. (2007). Service Management: Customer Management in Service Competition. London: John Wiley \& Sons Limited.

Hair, J. F., Hult, G. T. H., Ringle, C. M., \& Sarstedt, M. (2014). A Primer on Partial Least squares Structural Equation Modeling (PLS-SEM). Los Angeles, US: Sage.

Henseler, J., Ringle, C.M., \& Sinkovics, R.R. (2009). The Use of Partial Least Squares Path Modeling in International Marketing. Advances in International Marketing. 20: 277-320.

Hussain, R., Al-Nasser, A., \& Hussain, Y. K. (2015). Service Quality and Customer Satisfaction of a UAE-based airline: An Empirical Investigation. Journal of Air Transport Management. 42: 167-175.

Kang, B.S., Cho, C.H., \& Baek, J.D. (2007). The Effects of Service Quality on Customer Satisfaction in Case of Dissatisfied Customers. Asian Journal on Quality. 8 (1): 27 39.

Kitapcia, O., Akdogan, C., \& Dortyol, I.T. (2014). The Impact of Service Quality Dimensions on Patient Satisfaction, Repurchase Intentions and Word-of-Mouth Communication in the Public Healthcare Industry. Procedia - Social and Behavioral Sciences. 148 (2014) $161-169$. 
Relationship between Service Quality

Azman Ismail, Ilyani Ranlan Rose, Rabaah Tudin, Norazryana Mat Dawi

Kuo, Y.F., Wu, C.M., \& Deng, W.J. (2009). The Relationships Among Service Quality, Perceived Value, Customer Satisfaction, and Post-purchase Intention: in Mobile Value-added services. Computers in Human Behavior. 25 (4): 887-896.

Liat, C.B., Mansori, S., Chuan, G.C., \& Imrie, B.C. (2017). Hotel Service Recovery and Service Quality: Influences of Corporate Image and Generational Differences in The Relationship Between Customer Satisfaction and Loyalty. Journal of Global Marketing. 30 (1): 42-51.

Lobo, A., Maritz, A., \& Mehta, S. (2007). Enhancing Singapore Travel Agencies' Customer Loyalty: An Empirical Investigation of Customers' Behavioral Intentions and Zones of Tolerance. International Journal of Tourism Research. 9: 485-495.

Lu, N., \& Wu, H. (2016). Exploring the Impact of Word-of-Mouth About Physicians' Service Quality on Patient Choice Based on Online Health Communities. BMC Medical Informatics \& Decision Making. 16: 1-10.

Meštrović, D. (2017). Service quality, students' satisfaction and behavioural intentions in stem and ic higher education institutions. Interdisciplinary Description of Complex Systems. 15(1): 66-77.

Mohamed, B. \& Azizan, N. (2015). Perceived Service Quality's Effect on Patient Satisfaction and Behavioural Compliance. International Journal of Health Care Quality Assurance. 28 (3): 300-314.

Mosahab, R., Mahamad, O., \& Ramayah, T. (2010). Service Quality, Customer Satisfaction and Loyalty: a Test of Mediation. International Business Research. 3(4): 72-80.

Olorunniwo, F., \& Hsu, M.K. (2006). A typology analysis of service quality, customer satisfaction and behavioral intentions in mass services. Managing Service Quality: An International Journal. 16 (2): 106 - 123

Olorunniwo, F., Hsu, M.K., \& Udo, G.J. (2006). Service quality, customer satisfaction, and behavioral intentions in the service factory. Journal of Services Marketing. 20 (1): 59-72.

Ostrom, A. L., Parasuraman, A., Bowen, D. E., Patrício, L., Voss, C. A., \& Lemon, K. (2015). Service Research Priorities in a Rapidly Changing Context. Journal of Service Research. 18(2): 127-159.

Parasuraman, A., Zeithaml, V.A., \& Berry, L.L. (1985). A conceptual model of service quality and its implication for future research. Journal of Marketing. 49: 41-50. 
Parasuraman, A., Zeithaml, V.A., \& Berry, L.L. (1988). SERVQUAL: A Multiple-item Scale for Measuring Consumer Perceptions of Service Quality. Journal of Retailing. 64 (1): $12-40$.

Parasuraman, A., Berry, L.L., \& Zeithaml, V.A. (1991). Refinement and Reassessment of the SERVQUAL Scale. Journal of Retailing. 67 (4): 420-450.

Parasuraman, A., Zeithaml, V.A., \& Berry, L.L. (1994). Alternative Scales for Measuring Service Quality: A Comparative Assessment Based on Psychometric and Diagnostic Criteria. Journal of Retailing. 70 (3): 201-230.

Psomas, E. L., \& Jaca, C. (2016). The Impact of Total Quality Management on Service Company Performance: Evidence from Spain. International Journal of Quality \& Reliability Management. 33(3): 380-398.

Rahim, M., Osman, M., \& Ramayah, T. (2010). Service Quality, Customer Satisfaction and Loyalty: A Test of Mediation. International Business Research. 3 (4): 72-80.

Rosen, D.E., \& Surprenant, C. (1998). Evaluating Relationships: Are Satisfaction and Quality Enough?. International Journal of Service Industry Management. 9 (2):103 - 125.

Sadaf, F. (2017). Impact of Internet Banking Service Quality on Customer Satisfaction. Journal of Internet Banking and Commerce. 22: 1-17.

Saibou, H., \& Kefan, X. (2010). The relationships among quality, value, satisfaction and behavioral intention in health care provider choice: A study based on the case of Niger. IEEE, 6, 225-228. 2010, 2nd International Conference on Computer Engineering and Technology.

Saunders, S.G. (2008). Measuring and applying the PAKSERV service quality construct: Evidence from a South African cultural context. Managing Service Quality, 18(5), 442 -456 .

Sriram, S., Chintagunta, P. K., \& Manchanda, P. (2015). Service quality variability and termination behavior. Management Science. 61(11): 2739-2759.

Sureshchandar, G.S., Rajendran, C., \& Anantharaman, R.N. (2002). The Relationship Between Service Quality and Customer Satisfaction - a Factor Specific Approach. Journal of Services Marketing. 16(4): 363-379.

Taap, M.A., Chong, S.C., Kumar, M. and Fong, T.K. (2011). Measuring service quality of conventional and Islamic banks: a comparative analysis. International Journal of Quality and Reliability Management. 28 (8): 822-840. 
Relationship between Service Quality

Azman Ismail, Ilyani Ranlan Rose, Rabaah Tudin, Norazryana Mat Dawi

Udo, G.J., Bagchi, K.K., \& Kirs, P.J. (2010). An Assessment of Customers' e-service Quality Perception, Satisfaction and Intention. International Journal of Information Management. 30: 481-492

White, C., \& Yu, Y.T. (2005). Satisfaction Emotions and Consumer Behavioral Intentions. Journal of Services Marketing. 19 (6): 411 - 420.

Widarsyah, R., Ghiselli, R.F., \& Adler, H. (2017). Quality assurance in hospitality and tourism higher education: Administrators' view of ACPHA accreditation - an exploratory. Journal of Quality Assurance in Hospitality \& Tourism. 18 (2): 235-257.

Yaprakli, T.S., \& Tuzemen, A. (2017). Customer Perception of Bus Companies' Service Quality, Ataturk University Journal of Economics \& Administrative Sciences. 31 (3): 529542.

Yeo, G.T., Thai, V.V., \& Roh, S.Y. (2015). An Analysis of Port Service Quality and Customer Satisfaction: The Case of Korean Container Ports. The Asian Journal of Shipping and Logistics. 31(4): 437-447.

Yuen, K. F., \& Thai, V.V. (2015). Service quality and customer satisfaction in liner shipping. International Journal of Quality and Service Sciences. 7 (2/3): 170 - 183.

Zeithaml, V.A. (1988). Consumer Perceptions of Price, Quality, and Value: a Means-end Model and Synthesis of Evidence. Journal of Marketing. 52: 1-22.

Zeithaml, V.A., Parasuraman, A., \& Berry, L.L. (1990). Delivering Quality Service. New York: The Free Press.

Zeithaml, V.A., Berry, L.L., \& Parasuraman, A. (1996). The Behavioral Consequences of Service Quality. Journal of Marketing. 60(2): 31-46. 